\title{
PENGARUH KUALITAS PRODUK TERHADAP VOLUME PENJUALAN PADA HOME INDUSTRI KRIPIK TEMPE “ABADI" SINGGAHAN KECAMATAN KARTOHARJO KABUPATEN MAGETAN
}

\author{
Izzah Yuz Rifa Widyaningrum \\ Mahasiswa Prodi Pendidikan Ekonomi IKIP PGRI Madiun
}

\begin{abstract}
.
Quality is important in sales activities that need to be considered in order to meet the desires and expectations of consumers so that consumers will believe the products are made. In a study entitled "The Effect Of Quality Products At Home Sales Volume Industry Kripik Tempe" Abadi "Singgahan KartoharjoMagetan district" has a purpose: first to determine the quality of the Home Products Industry Kripik Tempe "Abadi" SinggahanKartoharjoMagetan district, both to determine the volume of sales in the Home Industries KripikTempe "Abadi" Singgahan District Kartoharjo Magetan.

Based on the results of data processing and simultaneous testing on a real level $(\alpha)$ $=5 \%$ indicates that the quality of the product simultaneously significantly influence Sales Volume At Home IndustryKripik Tempe "abadi" Singgahan District Kartoharjo Magetan. This is evident from the value of 20.638 while the value FcountFtable 4,042. On the other hand Sighit values of 0.000 and 0.05 Sigprob. This means that the value of F count $\geq$ Ftabel $(\geq 20.6384 .042)$ and Sighit $\leq$ Sigprob $(0.05 \leq 0.000)$. However, when seen from the regression equation factors positively influence the quality of the product shown in the regression equation obtained value equation $\mathrm{Y}=50.107+0.494 \mathrm{X}$.
\end{abstract}

Keywords: Quality, Product, Sales

\section{Pendahuluan}

Dalam pertumbuhan ekonomi di Negara Indonesia ini telah banyak berkembang berbagai usaha dari usaha kecil menengah sampai usaha yang berskala besar. Pemilik usaha saling berlomba untuk menawarkan produk-produk yang mereka ciptakan. Dari produk dibidang jasa dan dari produk barang. Para pemilik usaha saling mengatur strategi agar produk-produk mereka diminati oleh konsumen. Dengan adanya usaha baru yang berkembang dimasyarakat bisa mengurangi pengangguran yang berada di lingkungan sekitar usaha.

Musa Hubies ( 2009: 12) menyebutkan "dalam menghadapi perkembangan ekonomi nasional yang tidak lepas dari ekonomi regional dan global dengan segala bentuk peluang, ancaman, kekuatan dan kelemahan, diperlukan penciptaan iklim usaha yang kondusif dan paket program khusus yang dirancang secara 
terpadu, baik pendekatan untuk perorangan maupun kolektif yang sesuai dengan tahapan perkembangan permasalahan yang dihadapi”.

Home Industri biasanya memusatkan kegiatan usahanya di sebuah rumah keluarga tertentu dan biasanya para pekerjanya bertempat yang tak jauh dari rumah produksi. Karena secara letak dan emosional hubungan mereka sangat dekat (pemilik usaha dan pekerja), ini memungkinkan untuk menjalin komunikasi mereka. Dari kemudahan dalam berkomunikasi ini diharapkan para pekerja dapat bekerja dengan baik. Karena mereka merasa bahwa kegiatan usaha ini adalah milik keluarga, kerabat dan juga warga sekitar. Hal ini merupakan tanggung jawab bersama dalam upaya meningkatkan home industri mereka. Dengan begitu dapat mengurangi pengangguran yang berada disekitar home industri. Home industri ini memproduksi kripik tempe yang gurih dan lezat di daerah Kecamatan Kartoharjo Kabupaten Magetan, sebab didaerah ini belum ada home industri yang memproduksi kripik tempe. Home industri ini satu-satunya yang memproduksi kripik tempe selain itu home industri ini juga membuka peluang kerja bagi masyarakat sekitar sehingga dapat mengurangi pengangguran. Home industri ini usahanya semakin bertambah berkembang tiap tahunnya.

Garvin (dalam M.N. Nasution, 2001:16) menyebutkan "kualitas adalah suatu kondisi dinamis yang berhubungan dengan produk,manusia/tenaga kerja,proses dan tugas, serta lingkungan yang memenuhi atau melebihi harapan pelanggan atau konsumen". Sebagai penjual harus selalu memperhatikan kualitas produknya.Dorothea Wahyu (2003:11) menyebutkan "Kualitas akan membuat produk atau jasa dikenal, dan hal ini akan membuat perusahaan atau organisasi yang menghasilkan produk atau menawarkan jasa juga dikenal dan dipercaya masyarakat luas. Dengan demikian, tingkat kepercayaan pelanggan dan masyarakat umumnya akan bertambah dan organisasi atau perusahaan tersebut akan lebih dihargai. Hal ini akan menimbulkan fanatisme tertentu dari para konsumen terhadap produk apapun yang ditawarkan oleh perusahaan atau organisasi terebut".

Hani Handoko (2008:54) berpendapat bahwa "kualitas merupakan faktor yang terdapat dalam suatu produk yang menyebabkan produk tersebut bernilai sesuai dengan maksud untuk apa produk itu diproduksi.kualitas ditentukan oleh sekumpulan kegunaan (bundle of utilities) atau fungsinya, termasuk didalamnya daya tahan, ketidak tergantungan pada produk atau komponen lain, eksklusivitas, kenyamanan wujud luar (warna, bentuk,pembungkusan, dan sebagainya), dan harga yang ditentukan oleh biaya produk". Berdasarkan pengertian diatas Kualitas merupakan hal yang penting dalam kegiatan penjualan sehingga perlu diperhatikan agar dapat memenuhi keinginan dan harapan konsumen sehingga konsumen akan percaya dengan produk yang dibuat.

Kotler (dalam Freddy Rangkuti, 2009:126) menyebutkan " produk didefinisikan sebagai segala sesuatu yang dapat ditawarkan kepada pasar untuk mendapatkan perhatian, keahlian, kegunaan atau konsumsi yang memuaskan keinginan atau kebutuhan". Berdasarkan pengertian diatas produk merupakan suatu hasil yang dapat dijual dan dapat diterima oleh konsumen untuk memenuhi keinginan dan kebutuhan hidup agar tetap berlangsung. 
Freddy Rangkuti (2009:130) berpendapat bahwa "kualitas produk adalah satu dari salah satu alat yang paling sering digunakan oleh pemasar untuk melakukan positioning. Kualitas mempunyai imbas yang langsung terasa pada produk. Hal ini akan semakin mendekatkan pemasar dengan nilai-nilai pelanggan dan kepuasan pelanggan”. Juran (dalam M.N. Nasution, 2001:15) kualitas produk adalah kecocokan penggunaan produk (fitness for use) untuk memenuhi kebutuhan dan kepuasan pelanggan". Kualitas produk akan diminati oleh para konsumen, walaupun dengan harga mahal ataupun murah, pasti dicari asalkan produk tersebut nyaman, puas dan bermanfaat setelah melakukan pembelian.

Berdasarkan pengertian diatas dapat disimpulkan bahwa kualitas produk adalah kesesuaian konsumen terhadap mutu barang atau produk yang dibeli untuk memenuhi segala kubutuhan.

Klasifikasi Produk

Kotler dan Armstrong (2006:269) menyebutkan “ produk dan Jasa dibagi menjadi dua kelompok besar berdasarkan tipe konsumen yang menggunakannya yaitu: 1) Produk konsumen dan 2) produk industri .

1) produk konsumen adalah produk dan jasa yang dibeli oleh konsumen akhir untuk konsumsi pribadi". Produk ini bisa langsung dipakai oleh konsumen tanpa harus mengolahnya lagi. "Produk konsumen ini meliputi a) produk kebutuhan sehari-hari adalah Produk dan jasa konsumen yang biasanya sering segera dibeli pelanggan, b) produk belanja adalah Produk dan jasa konsumen yang lebih jarang dibeli dan pelanggan membandingkan kecocokan, kualitas harga dan gaya produk secara cermat, c) produk khusus adalah produk dan jasa konsumen dengan karakteristik unik atau identifikasi merk dimana sekelompok pembeli signifikan bersedia melakukan usaha pembelian khusus d) produk tak dicari adalah produk konsumen yang mungkin tidak dikenal konsumen atau produk yang mungkin dikenal tetapi biasanya konsumen tidak berpikir untuk membelinya.

2) produk industri adalah produk yang dibeli untuk pemrosesan lebih lanjut atau untuk digunakan dalam menjalankan suatu bisnis... perbedaan antara produk konsumen dan produk industri didasarkan pada tujuan untuk apa produk itu dibeli. Tujuan produk ini dibeli tergantung dari pembelinya, misalnya: tepung terigu dikonsumsi oleh ibu rumah tangga untuk membuat adoan kuenya maka tepung terigu ini sebagai produk konsumen. Dan apabila tepung terigu ini dibeli untuk membuat adonan kripik tempe dan kripik tempe tersebut dijual kepada konsumen maka tepung tersebut sebagai produk industri.

Dimensi Kualitas Produk

Menurut Garvin ( dalam M.N.Nasution, 2000:17) mendefinisikan delapan dimensi yang dapat digunakan untuk menganalisis karakteristik kualitas produk yaitu :

1) Kinerja ( Performance) kinerja berkaitan dengan aspek fungsional dari produk dan merupakan karakteristik utama yang dipertimbangkan pelanggan ketika ingin membeli suatu produk.

2) Karakteristik Pelengkap atauTambahan (Features) Martinich (dalam Zulian Yamit, 2005:11) berpendapat "selain fungsi utama dari suatu produk dan 
pelayanan, pelanggan sering kali tertarik pada kemampuan atau keistimewaan yang dimiliki produk dan pelayan.

3) Kehandalan (Reliability) Zulian Yamit (2005:10) berpendapat "kehandalan yaitu kemungkinan tingkat kegagalan pemakaian". Martinich ( dalam Zulian Yamit, 2005:10) reliability yaitu kehandalan produk dalam penggunaan secara normal.

4) Kesesuaian (convormance) Garvin ( M.N.Nasution, 2000:17) menyebutkan bahwa "berkaitan dengan tingkat kesesuaian produk terhadap spesifikasi yang telah ditetapkan sebelumnya berdasarkan keinginan pelanggan.

5) Daya Tahan (Durability) Berapa lama produk dapat terus digunakan" (Zulian Yamit, 2005:10). Garvin ( M.N.Nasution, 2000:18) berpendapat "ukuran masa pakai suatu produk. Karakteristik ini berkaitan dengan daya tahan dari suatu produk.

6) kemampuan Pelayanan (Serviceability) Kecepatan, kompetensi, kenyamanan, kemudahan dalam pemeliharaan dan penanganan keluhan yang memuaskan" (Zulian Yamit, 2005:10).

7) Estetika Martinich (dalam Zulian Yamit, 2005:11). Menyebutkan “ penampilan, corak, rasa, daya tarik, bau, selera, dan beberapa faktor lainnya mungkin menjadi aspek penting dalam kualitas". Hal ini sangat penting sekali untuk diperhatikan sebelum memproduksi suatu barang atau produk. Konsumen pasti akan memperhatikan penampilan, corak dan yang paling penting adalah rasa.

8) Kualitas yang Dipersepsikan ( Perceived) Garvin ( M.N.Nasution, 2000:18) menyebutkan "karakteristik ini bersifat subyektif, berkaitan dengan perasaan pelanggan dalam mengkonsumsi produk, seperti meningkatkan harga diri".

Pengukuran Kualitas Produk

Pengukuran kualitas dapat dilakukan melalui perhitungan biaya kualitas dan melalui penelitian pasar mengenai persepsi konsumen terhadap kualitas produk".(Zulian Yamit,2005:19).

1) Perhitungan biaya kualitas dapat Perhitungan Biaya Kualitas. menurut Pengukuran kualitas melalui penghitungan biaya kualitas dapat dilakukan dengan berbagai cara yaitu : a) Biaya kualitas diukur berdasarkan biaya kerusakan perjam dari tenaga kerja langsung. b) Biaya kualitas diukur berdasarkan biaya produksi termasuk biaya tenaga kerja langsung, biaya bahan baku dan biaya overhead pabrik. c) Biaya kualitas diukur berdasarkan penjualan bersih.

2) Penelitian Pasar Mengenai Persepsi Konsumen, Penelitian ini bisa dilakukan dengan peneliti menemui para konsumen dipasar dengan mewawancarai langsung atau dengan memberikan angket atau kuesioner tentang kualitas produk suatu barang yang dibeli. Dengan begitu bisa mengetahui kualitas dari produk tersebut.

Freddy Rangkuti (2009:57) berpendapat "Penjualan pengalihan hak milik atas barang dengan imbalan uang sebagai gantinya dengan persetujuan untuk menyerahkan barang kepada pihak lain dengan menerima pembayaran". Tujuan pemilik usaha dalam memproduksi barang adalah untuk mendapatkan untung dari hasil penjualan yang dilakukannya, kesuksesan usaha penjualan dapat dilihat dari volume penjualan tiap bulannya, apakah mendapat laba atau mengalami kerugian. 
Menurut Freddy Rangkuti (2009:57) "volume penjualan adalah pencapaian penjualan yang dinyatakan secara kuantitatif dari segi fisik atau volume atau unit suatu produk". Naik turunnya penjualan bisa dilihat dari unit, kilogram, liter dari hasil penjualan produk. Dari uraian di atas maka penulis menyimpulkan bahwa volume penjualan merupakan hasil keseluruhan dari penjualan suatu barang yang diperoleh pemilik usaha atau perusahaan dalam jangka waktu tertentu.

Basu Swastha (2008:406) menyebutkan "kegiatan penjualan dipengaruhi oleh beberapa faktor-faktor yaitu :

1) Kondisi dan kemampuan Penjual, Basu Swastha (2008:406) menyebutkan "Penjual harus dapat menyakinkan pembelinya agar berhasil menjual produk-produknya dan mencapai sasaran penjualan yang diharapkan". a) Karakteristik Produk Garvin (dalam M.N. Nasution, 2001:17) menyebutkan "Performa berkaitan dengan aspek fungsional dari produk dan merupakan karakteristik utama yang dipertimbangkan pelanggan ketika ingin membeli suatu produk". b) Harga Produk, Basu Swastha (2008:406) menyebutkan "Syarat penjualan seperti, pembayaran, penghantaran, pelayanan sesudah penjualan, garansi dan sebagainya.

2) Kondisi Pasar, Basu Swastha (2008:138) menyebutkan "Pasar, sebagai kelompok pembeli atau pihak yang menjadi sasaran dalam penjualan". Faktor faktor kondisi pasar yang perlu diperhatikan: a) Pasar konsumen, didalam pasar konsumen ini terdiri dari para konsumen akhir yang memakai produk siap pakai tanpa harus mengolahnya lagi. Misalkan produk makanan ringan, pakaian dan lain sebagainya. b) Kelompok Pembeli, Pelaku usaha harus bisa mengetahui kelompok-kelompok pembeli. Sebaiknya penjual melakukan observasi terhadap pembeli yang ada di pasar konsumen, sehingga produk yang diciptakant tepat sasaran dan sesuai dengan kalangan pembeli. c) Daya Beli, Penjual hendaknya mengetahui kondisi atau daya beli para pembeli, sehingga saat membuat produk tidak mengalami kegagalan saat menjual produknya. Sehingga produknya bisa mampu dibeli oleh konsumen dengan harga terjangkau. d) Keinginan dan Kebutuhannya, Pelaku usaha harus bisa mengetahui atau memprediksi kebutuhan dan keinginan konsumen dan pelanggannya, agar produk yang dibuat bisa berhasil mencapai tujuan yang diharapkan dan agar tidak menjadi produk yang gagal.

3) Modal, Basu Swastha (2008:407) menyebutkan "Diperlukannya adanya sarana serta usaha, seperti: alat transport, tempat peragaan baik didalam atau diluar perusahaan, usaha promosi".

4) Kondisi Organisasi Perusahaan, Basu Swastha (2008:407) menyebutkan "Pada perusahaan kecil dimana masalah penjualan ditangani oleh orang yang juga melakukan fungsi-fungsi lain.... Biasanya masalah penjualan ini ditangani sendiri oleh pimpinan dan tidak diberikan kepada orang lain". Semuanya dilakukan sendiri, sebab jumlah tenaga kerjanya yang sedikit dan manajemen lebih sederhana.

5) Faktor lain, Basu Swastha (2008:407) menyebutkan "Faktor lain seperti, periklanan, peragaan, kampanye, pemberian hadiah". 


\section{METODE PENELITIAN}

Dalam rancangan penelitian harus dapat menemukan metode yang tepat, karena metode merupakan suatu dasar yang penting dalam penelitian. Tanpa metode, penelitian tidak akan terarah dan terfokus. Metode lebih menekankan pada cara yang digunakan untuk melaksanakan proses agar tujuan penelitian tercapai sesuai dengan yang dikehendaki. Menurut Gabriel (2003: 96) "Metode penelitian menguraikan bagaimana data yang diperlukan untuk menguji hipotesa dan menjawab masalah yang dikumpulkan dari sumber-sumber yang telah ada". Menurut Moh Nazir (2003:84) desain penelitian adalah "semua proses yang diperlukan dalam perencanaan dan pelaksanaan penelitian". Berdasarkan penjelasan diatas bahwa dalam penelitian harus merencanakan apa yang akan diperlukan dalam pelaksanaan penelitian agar dapat diperoleh suatu logika, baik dalam pengujian hipotesis atau dalam kesimpulan.

Sehubungan dengan penelitian ini peneliti menentukan dua variabel yaitu variabel bebas $(\mathrm{X})$ adalah kualitas produk dan variabel terikat $(\mathrm{Y})$ adalah volume penjualan.

Populasi dalam penelitian ini adalah pelanggan dari Home Industri kripik tempe "Abadi". Dalam penelitian ini, peneliti menggunakan teknik pengambilan sampel jenuh. Menurut Gabriel Amin Silalahi (2003: 76) Sampel jenuh adalah "teknik penentuan sampel bila semua anggota populasi digunakan sebagai sampel”. Berarti sampel yang digunakan sebagai objek penelitian sebanyak 50 pelanggan. Karena populasinya sebesar 50 orang pelanggan.

\section{HASIL PENELITIAN}

\section{Variabel Kualitas Produk}

Variabel kualitas produk dapat dideskripsikan bahwa variabel kualitas produk dengan jumlah $\mathrm{N}$ sebanyak 50 pelanggan, bahwa hasil kuesioner yang memperoleh nilai diatas rata-rata $\geq 93,62$ sebanyak 27 pelanggan atau $54 \%$. Sedangkan yang berada dibawah nilai rata-rata sebanyak 23 pelanggan atau $46 \%$. Dari hasil pengujian statistik deskriptif di atas dapat diketahui jumlah total 4681 dan standar deviasi sebesar 14,068 dengan jumlah responden sebanyak 50 diketahui statistik deskriptifnya sebagai berikut : a) Nilai mean sebesar 93,62; b) Nilai median sebesar 97,50; c) Nilai modus sebesar 100; d) Nilai minimum sebesar 51; e) Nilai maksimum sebesar 119.

\section{Variabel Volume Penjualan}

Variabel Volume Penjualan dapat dideskripsikan bahwa variabel volume penjualan dengan jumlah $\mathrm{N}$ sebanyak 50 pelanggan, bahwa hasil penjualan yang memperoleh nilai diatas rata-rata $\geq 96,32$ sebanyak 21 bulan atau $42 \%$ (lihat lampiran 12). Sedangkan yang berada dibawah nilai rata-rata sebanyak 29 bulan atau 58\%. Dari hasil pengujian statistik deskriptif di atas dapat diketahui jumlah total 4816 dan standar deviasi sebesar 12,664 dengan jumlah sebanyak 50 diketahui statistik deskriptifnya sebagai berikut : a) Nilai mean sebesar 96,32 ; b) 
Nilai median sebesar 95,00; c) Nilai modus sebesar 90; d) Nilai minimum sebesar 75; e) Nilai maksimum sebesar 150.

\section{Hasil Uji F/ Fisher}

\begin{tabular}{|l|c|r|c|c|c|}
\hline Model & $\begin{array}{c}\text { Sum of } \\
\text { Squares }\end{array}$ & df & $\begin{array}{c}\text { Mean } \\
\text { Square }\end{array}$ & F & Sig. \\
\hline Regression & 2363,029 & 1 & 2363,029 & 20,638 &, $000^{\mathrm{a}}$ \\
Residual & 5495,851 & 48 & 114,497 & & \\
Total & 7858,880 & 49 & & & \\
\hline
\end{tabular}

a. Predictors: (Constant), kualitas_produk

b. Dependent Variable: volume_penjualan

Berdasarkan uji $\mathrm{F}$ dapat diketahui nilai $\mathrm{F}_{\text {hitung }}$ sebesar 20,638 sedangkan nilai $\mathrm{F}_{\text {tabel }}$ sebesar 4,042. Dilain pihak nilai $\mathrm{Sig}_{\text {hit }}$ sebesar 0,000 dan $\mathrm{Sig}_{\text {prob }}$ sebesar 0,05. Hal ini berarti bahwa nilai $F_{\text {hitung }} \geq F_{\text {tabel }}(20,638 \geq 4,043)$ dan Sig hit $\leq$ $\operatorname{Sig}_{\text {prob }}(0,000 \leq 0,05)$. Hal ini dapat dikatakan bahwa $\mathrm{H}_{0}$ ditolak, artinya ada pengaruh kualitas produk dengan volume penjualan pada Home Industri Kripik Tempe "Abadi” Singgahan Kecamatan Kartoharjo Kabupaten Magetan.

\section{Simpulan Hasil Analisis}

Berdasarkan analisis data yang telah di dapatkan maka dapat dibuat kesimpulan sebagai berikut.

\section{Simpulan Uji Fisher}

Dari hasil analisis data untuk uji Fisher dalam penelitian ini dapat diperoleh hasil nilai $F_{\text {hitung }}$ sebesar 20,638 sedangkan nilai $F_{\text {tabel }}$ sebesar 4,043. Dilain pihak nilai $\mathrm{Sig}_{\text {hit }}$ sebesar 0,000 dan $\mathrm{Sig}_{\text {prob }}$ sebesar 0,05. Hal ini berarti bahwa nilai $F_{\text {hitung }} \geq F_{\text {tabel }}(20,638 \geq 4,043)$ dan $\operatorname{Sig}$ hit $\leq \operatorname{Sig}_{\text {prob }}(0,000 \leq 0,05)$. Dengan demikian dapat disimpulkan bahwa $\mathrm{H}_{0}$ ditolak, artinya ada pengaruh kualitas produk terhadap volume penjualan pada Home Industri Kripik Tempe "Abadi" Singgahan Kartoharjo Magetan.

\section{Pembahasan Uji Fisher}

Untuk uji Fisher diperoleh nilai $F_{\text {hitung }}(20,638)>F_{\text {tabel }}(4,043)$ atau $\operatorname{Sig}_{\text {hit }}$ $(0,000) \leq \operatorname{Sig}_{\text {prob }}(0,05)$. Dengan hal ini $\mathrm{H}_{0}$ ditolak, artinya ada pengaruh kualitas produk dengan volume penjualan pada Home Industri "Kripik Tempe Abadi" Singgahan Kartoharjo Magetan. 


\section{PENUTUP \\ Simpulan}

Berdasarkan hasil analisis data dan pembahasan pada bab sebelumnya dapat disimpulkan sebagai berikut:

Kualitas produk kripik tempe "Abadi” baik. Kualitas produk yang dirasakan oleh pelanggan mulai dari rasa, corak, daya tarik dari kripik tempe ini selalu meningkat dan pelanggan merasa puas dan percaya dengan kualitas kripik tempe sehingga membuat jumlah pelanggan bertambah. Berdasarkan hasil kuesioner yang memperoleh nilai diatas rata-rata $\geq 93,62$ sebanyak 27 pelanggan atau $54 \%$ ini dapat dikatakan bahwa kualitas produk dari kripik tempe "Abadi” baik.

Volume penjualan pada Home Industri Kripik Tempe "Abadi” Singgahan Kecamatan Kartoharjo Kabupaten Magetan yang tiap bulanpenjualannya mengalami peningkatan dan penurunan ini disebabkan penjualan meningkat, pada saat musim lebaran banyak pesanan dan banyak pembeli yang menjadikan buat oleh-oleh dan disaat bahan baku kedelai yang harganya stabil. Dan disaat penjualan menurun disebabkan harga bahan baku kedelai mahal ini membuat jumlah produksi tidak bisa menjadi lebih banyak. Hal ini terbukti dari hasil penjualan kripik tempe yang selalu mengalami naik turun dengan hasil produksi kripik tempe yang baik sekali, dengan penjualan yang memperoleh nilai diatas rata-rata $\geq 96,32$ sebanyak 21 bulan atau $42 \%$.

Kualitas produk berpengaruh terhadap volume penjualan pada Home Industri Kripik Tempe "Abadi" Singgahan Kecamatan Kartoharjo Kabupaten Magetan. Karena dengan adanya kualitas produk yang baik, menjadikan volume penjualan pun ikut meningkat. Hal ini diperkuat dengan adanya hasil penelitian yaitu hasil uji Fhitung sebesar 20,638 sedangkan nilai Ftabel sebesar 4,042. Hal ini berarti bahwa Fhitung $\geq$ Ftabel $(20,638 \geq 4,043)$. Uji tersebut mengarah pada satu simpulan bahwa ada penolakan pada ${ }_{\mathrm{H} 0}$, yang artinya kualitas produk mempunyai pengaruh terhadap volume penjualan, khususnya pada Home Industri Kripik Tempe "Abadi" Singgahan Kecamatan Kartoharjo Kabupaten Magetan.

\section{Saran}

Dari kesimpulan penelitian tentang kualitas produk terhadap volume penjualan pada Home Industri "Kripik Tempe Abadi" Singgahan Kartoharjo Magetan. Adapun saran yang dapat dikemukakan dalam akhir penyusunan laporan penelitian ini antara lain sebagai berikut :

\section{Pemilik Home Industri}

Pemilik diharapkan dapat memperhatikan dan memberikan kualitas produk yang baik sehingga dapat memuaskan para pelanggan, sehingga pelanggan tetap mau untuk mengkonsumsi kripik tempe dan tidak beralih ke produk lain.

\section{Karyawan}

Karyawan diharapkan dapat meningkatkan kualitas kripik tempe kepada pelanggan dan bersungguh-sungguh untuk membuat kripik tempe yang lebih baik agar pelanggan tetap loyal.

\section{Bagi Peneliti Mendatang}


Bagi peneliti yang akan datang sebaiknya dapat mengembangkan atau mencari variabel lain, selain kualitas produk karena masih banyak faktor lain yang harus diteliti yang dapat mempengaruhi volume penjualan.

\section{DAFTAR PUSTAKA}

Basu Swastha dan Irawan. 2008. Manajemen Pemasaran Modern. Yogyakarta : Liberty Offset.

Dorothea Wahyu Ariani. 2003. Manajemen Kualitas Pendekatan Sisi Kualitatif. Jakarta : Ghalia Indonesia.

Duwi Priyatno. 2010. Teknik Mudah dan Cepat Melakukan Analisis Data Penelitian SPSS dan Tanya Jawab Ujian Pendadaran

Fandy Tjiptono dan Anastasia Diana. 2000. Total Quality Management. Yogyakarta : ANDI.

Freddy Rangkuti. 2009. Strategi Promosi Yang Kreatif dan Analisis Kasus Integrated Marketing Communication. Jakarta : PT Gramedia Pustaka utama.

Gabriel Amin Silalahi. 2003. Metodologi Penelitian dan Studi Kasus. Sidoarjo : Citra Media.

Hani Handoko. 2008. Dasar- Dasar Manajemen Produksi dan Operasi. Yogyakarta : BPFE.

Husaini dan Purnomo. 2006. Pengantar Statistika. Jakarta : Bumi Aksara.

Iqbal Hasan. 2004. Analisis Data Penelitian Dengan Statistik. Jakarta : PT Bumi Aksara.

Juliansyah Noor.2011. Metodologi Penelitian. Jakarta : Kencana Prenada Media Group.

Kotler dan Armsstrong. 2006. Prinsip-Prinsip Pemasaran. Jakarta : Erlangga.

Kotler dan Susanto. 2000. Manajemen Pemasaran Di Indonesia Analisis, Perencanaan, Implementasi dan Pengendalian. Jakarta : Salemba Empat.

M.N Nasution. 2001. Manajemen Mutu TerpadU. Jakarta : Ghalia Indonesia.

Moh. Nazir. 2003. Metode Penelitian. Jakarta : Ghalia Indonesia.

Mursid. 2010. Manajemen Pemasaran. Jakarta : PT Bumi Aksara. 
Musa Hubies. 2009. Prospek Usaha Kecil dalam Wadah Inkubator Bisnis. Jakarta : Ghalia Indonesia.

Sugiyono.2008. Metode Penelitian Kuantitatif, Kualitatif, Dan R\&D. Bandung : Penerbit Alfabeta.

Sugiyono.2010. Metode Penelitian Kuantitatif, Kualitatif, Dan R\&D. Bandung: Penerbit Alfabeta.

Suharsimi Arikunto. 2005. Manajemen Penelitian. Jakarta: PT Rineka Cipta.

Suharsimi Arikunto. 2010. Prosedur Penelitian Suatu Pendekatan Praktik. Jakarta : Rineka Cipta.

Supranto. 2008. Statistik Teori dan Aplikasi. Erlangga

Zulian Yamit. 2005. Manajemen Kualitas Produk dan Jasa. Yogyakarta : Penerbit EKONISIA. 